\title{
DELAYED RETURN: CONSOLIDATION OF THE ZIMBABWEAN DIASPORA AND TRANSNATIONALISM
}

\author{
Retorno adiado: consolidação da diáspora do Zimbábue \\ e Transnacionalismo
}

Rose Jaji*

\begin{abstract}
This article discusses consolidation of the Zimbabwean diaspora and its transnational activities. It presents formation of this particular diaspora as an unanticipated development that is contingent upon circumstances as they evolve in both sending and receiving countries. It draws from longitudinal research with Zimbabwean migrants in Germany and South Africa to illustrate this argument. It also borrows from Tsuda's transnational outcome framework to provide a nuanced understanding of Zimbabwean migrants' varied relationships with both Zimbabwe and the receiving countries. The article argues that migrants' decision to settle for the long-term in the receiving country is not always made at the same time as the decision to migrate itself or in the initial stages of life in the receiving country. There are many cases among Zimbabwean migrants showing that migration was initially perceived as quest for reprieve from the country's economic and political challenges while they "waited" for the situation to improve. However, the crisis in Zimbabwe has dragged on for more than two decades with no tangible solution in sight thus transforming waiting into settling. Economic and political factors in Zimbabwe as well as factors in the receiving countries influenced the formation and consolidation of the Zimbabwean diaspora and its transnational activities. Diaspora formation and consolidation in this case is an outcome of migrants' adaptation of their initial plans to new realities obtaining in both the sending and receiving countries.
\end{abstract}

Keywords: transnational outcomes; diaspora; Zimbabwe.

Resumo. Este artigo discute a consolidação da diáspora do Zimbábue e suas atividades transnacionais. Apresenta a formação desta diáspora particular como um desenvolvimento imprevisto que depende das circunstâncias à medida que evoluem nos países de origem e de destino. Baseado em pesquisas longitudinais com migrantes do Zimbábue na Alemanha e na África do Sul para ilustrar esse argumento. Também toma emprestado da estrutura de resultados transnacionais de Tsuda para fornecer uma compreensão diferenciada das relações variadas dos migrantes do Zimbábue com o Zimbábue e os países de destino. $O$ artigo argumenta que a decisão dos migrantes de se estabelecer por um longo prazo no país de destino nem sempre é tomada ao mesmo

Senior lecturer in the Department of Sociology at the University of Zimbabwe. Harare, Zimbabwe. E-mail: rose.jaji@yahoo.com. Orcid: https://orcid.org/0000-0003-0266-8541. 
tempo que a decisão de migrar em si ou nos estágios iniciais da vida no país de destino. Há muitos casos entre os migrantes do Zimbábue que mostram que a migração foi inicialmente percebida como uma busca por alívio dos desafios econômicos e políticos do país enquanto eles "esperavam" que a situação melhorasse. No entanto, a crise no Zimbabué prolongou-se por mais de duas décadas sem nenhuma solução tangível à vista, transformando assim a espera em resolução. Fatores econômicos e políticos no Zimbábue, bem como fatores nos países receptores, influenciaram a formação e consolidação da diáspora zimbabweana e suas atividades transnacionais. A formação e consolidação da diáspora, neste caso, é o resultado da adaptação dos migrantes de seus planos iniciais às novas realidades existentes nos países de origem e de destino.

Palavras-chave: resultados transnacionais; diáspora; Zimbábue.

\section{Introduction}

It is not uncommon for migrants to leave their countries of origin with the vision that their migration will be of temporary and short duration. In such instances, migration is perceived as taking a break from an intractable economic and political situation or a strategy to meet an identified need such as saving money for investment back in the sending country. In this context, the logical course of action after saving money to solve the economic problems and meet the identified need is to return to the sending country in what Cerase (1974) identified as return of conservatism. However, there are numerous migration routes around the world that show that migrations initially envisaged as ephemeral morph over time into permanent settlements in response to evolving factors in both sending and receiving countries. Indeed, transformation of short-term stays to long-term settlement is the essence of diaspora communities. This transformation has varied results that are discussed in this article using Tsuda's (2012) formulation of transnational outcomes. Long-term settlement potentially creates networks that open channels for more migrants leading to increase in volume of migration along the same routes and formation of diaspora communities. This article discusses migration from Zimbabwe in the last two decades and the formation and consolidation of the Zimbabwean diasporas in Germany and South Africa. It addresses migrants' initial views of their mobility and how these views morph over time contingent upon factors in both Zimbabwe and the receiving countries. This transformation of migrants' perception of their movement and circumstances is relevant to an understanding of Zimbabweans' motivations for migration, their intertwinement with other post-migration considerations, and their crystallization over time into a Zimbabwean diaspora.

\section{Germany and South Africa: The Researches}

This article is based on two qualitative researches carried out with Zimbabwean migrants in Germany and South Africa. The first phase was conducted 
in 2006-7 with Zimbabweans based in Germany and in 2010-11 with migrants in South Africa. The second phase which was follow-up research was done in 2015-16 with migrants in both countries and it mainly focused on changes that had occurred in the migrants' lives since the first phase of the research. In both researches, participants were identified through snowball sampling in which the researcher started with migrants that she knew from Zimbabwe and asked them to refer her to other Zimbabwean migrants they knew. Ten women and fifteen men were interviewed in Germany while thirteen women and seven men living in South Africa were interviewed. Data in both studies were collected through semi-structured interviews. In Germany, the research involved both face-to-face and telephone interviews while the interview with migrants in South Africa were carried out in-person in 2010-11 and via WhatsApp in 2015-16 as the researcher had left South Africa by this time. An interesting aspect of the researches is that data were obtained not only through the formal research process but also through informal conversations that touched on themes relevant to the research. These conversations were useful in their spontaneity because research participants provided more detailed information on their migration goals and future plans. Information yielded by these conversations was integrated into the research data with the full knowledge and informed consent of the research participants. Continuing growth of the Zimbabwean diaspora translates into a complex interplay of factors which, combined with the methodological approach to the researches upon which this article is based, means that the findings discussed in this article cannot be generalized to all Zimbabwean migrants in the two receiving countries and elsewhere.

\section{Overview of the Context of Migration from Zimbabwe}

Although Zimbabwe was born out of a bitter armed struggle for independence from Britain, it emerged at independence on 18 April 1980 as an economically and politically stable country which boasted of the second largest economy in Southern Africa after South Africa. However, in the 1990s, the country adopted the neoliberal Economic Structural Adjustment Program (ESAP) which, contrary to its anticipated outcomes, led to company closures, retrenchment of workers, strikes, food riots, and deterioration of standards in its social services sector (Raftopoulos, Sachikonye, 2001; Sachikonye, 1995). A major challenge in Zimbabwe's economic decline is inflation which reached 89.7sextillion percent (Hanke, Kwok, 2009). Erosion of incomes saw professionals such as doctors and nurses leave the country search of higher remuneration and better working conditions. Zimbabwe's well-organized social services sector was severely affected and the progress made in the early of years of independence eroded (Kawewe, Dibie, 2000). At the turn of the century, the government embarked on a land reform program which saw seizure of white-owned commercial farms. The chaotic nature of the seizures had a drastic impact on the agricultural sector which is the 
mainstay of the Zimbabwean economy (Maiyaki, 2010). Zimbabwe has largely been in shambles in the last twenty years. It had a brief respite from its currency instability when it adopted in 2009 a multi-currency regime dominated by the United States dollar. The multi-currency regime subsisted until 2019 (Jefferies, 2020). However, the United States dollar continues to be legal tender as citizens remain reluctant to embrace the unpredictable local currency.

On the political front, disaffection with the economic state of affairs in the country and increasing repression gave birth to the opposition party Movement for Democratic Change (MDC) in 1999. This party would go on to pose a serious challenge to the ruling Zimbabwe African Union Patriotic Front (ZANU PF) which has been at the helm since independence. The rancorous political contest between the two parties continues unabated with the state resorting to violent clampdown on opposition party members (Alexander, McGregor, 2013). The violence forced some opposition party members and supporters to flee the country. As such, economic and political problems emerged during the same period and this combination turned out to be a decisive factor in migration from Zimbabwe (Pasura, 2010). The intertwinement of political and economic problems produced a population of migrants consisting of both people looking for better economic prospects and others seeking political asylum or both. This combination of economic and political instability has resulted in movement of people from Zimbabwe being described as "mixed migration" (Block, 2008; Crush, Chikanda, Tawodzera, 2015; de Jager, Musuva, 2015). It also fits into what Castles (2018) terms "emergency migration". While migration has been an integral part of Zimbabwe's precolonial, colonial, and postcolonial history, it had not been to the level witnessed at the turn of the twenty-first century which saw what can be described as an exodus out of the country (Crush, Tevera, 2010). Although migration from post-independence Zimbabwe became noticeable in the 1990s following economic decline caused by adoption of ESAP, the largest number migrated around 2000 (Bloch, 2008).

\section{Mobility from Zimbabwe in the Early 2000s}

Although Zimbabwe's precolonial and colonial history is intertwined with inward- and outward-bound mobility, outward-bound migration from Zimbabwe increased to an unprecedented level and turned the country into a sending country when the economic and political situation in the country deteriorated at the turn of the twenty-first century (see de Jager, Musuva, 2015; Mlambo, 2010). In the last two decades, Zimbabweans have moved mostly to neighboring countries such as South Africa and Botswana and as far afield as the United Kingdom, the United States, Canada, Australia, and New Zealand among others. While Zimbabweans predominantly migrated to English-speaking countries, more people than was previously the case also migrated to non-English speaking countries such as Germany as shown by migrants who participated in the research that I conducted 
in Germany. Although Zimbabweans engaged in international migration before the onset of the economic and political problems in the country, they did so in relatively insignificant numbers. Prior to the onset of the economic and political difficulties, Zimbabwe received migrants from neighboring countries and beyond who saw economic prospects in the country's then stable economy (see Crush, Tevera, 2010; Jaji, 2020; Mlambo, 2010). It was not until the high-volume mobility of the last two decades that the term diaspora creeped into Zimbabwean parlance. The Zimbabwean diaspora can thus be regarded as having been consolidated in the last two decades in which the economic and political crisis propelled unprecedented numbers of people to leave the country.

Migrants who participated in the two researches conceptualized their migration during its early years as a short-term response to what they believed would be a transitory political and economic crisis. This understanding of migration could be detected in migrants' narratives in the early years of life in their receiving countries. Migrants who participated in the research mostly held the Zimbabwean passport and identified as Zimbabweans. For instance, Nyasha explained, "I am still Zimbabwean. This passport is only for work purposes". The research participants also referred to Zimbabwe as home which they took as their point of reference in conversations relating to their lives in the receiving country. This is not unique to Zimbabwean migrants who participated in the researches as it has also been noted among Zimbabweans in the United Kingdom by Pasura (2011). For Christian migrants such as members of a Pentecostal church known as Zimbabwe Assemblies of God Africa (ZAOGA), their church fostered a theology that depicted Zimbabwe as morally superior to their receiving countries which was the migrants' spiritual and cultural home (Biri, 2014). Zimbabwean migrants' narratives mostly harked back to Zimbabwean cultures as could be heard in comments that disapproved of marriages of convenience meant to accelerate acquisition of German documents.

Conversely, they would also criticize Zimbabwean cultures as unhelpful because they made the migrants stick to legal ways of doing things without resorting to shortcuts. The irony is that while the refrain "the Zimbo [Zimbabwean] way of doing things will get you nowhere" could be heard during the interviews, the migrants were not prepared to relinquish Zimbabwean cultures. Migrants who were still unmarried talked about their families of birth back in Zimbabwe and their plans revolved around these families and the country. Migrants who had lived in Germany for less than five years at the time of the research spoke about returning to Zimbabwe once the situation had improved. For migrants living in South Africa, the country's proximity to Zimbabwe enabled them to effortlessly blend Zimbabwe into their narratives and activities because they were in more regular contact not only with many other Zimbabwean migrants but also with the country itself which they could visit regularly. Unlike Germany, it is easier for migrants to even send 
money and parcels to family back in Zimbabwe through other migrants, visiting relatives, and bus drivers plying the South Africa-Zimbabwe route.

Although migrants still show interest in political and economic developments in Zimbabwe (Bloch, 2008), they have embraced their receiving country as home. Two main factors can be raised on this. Firstly, the crisis which they initially perceived as short-term has turned out to be protracted and intractable. Secondly, their children who either came to Germany or South Africa when they were young or were born in these countries have grown up in the diaspora and consider the receiving country as home. Lack of knowledge about and/or interest in Zimbabwe means that this generation is detached from the idea of Zimbabwe being home. For many young Zimbabweans who have grown up in the diaspora, Zimbabwe is their parents' home and not theirs. Recognizing this difference, many parents have adapted to this reality by relinquishing Zimbabwean parenting styles and adopting host country ones as the prospect of these children having the need to integrate into Zimbabwean society becomes a mirage. For example, Charlene, a migrant woman who moved to South Africa when her son was still a toddler, explained that he spoke Zulu, a South African language, better than he spoke Shona which is spoken in Zimbabwe.

\section{Zimbabwean Diaspora and Transnational Lives}

Diaspora formation and consolidation do not have a single outcome for migrants. Transnational activities vary within the same diaspora community (Al-Ali et al., 2001). As migrants settle in the receiving country for the long-haul, this has varied outcomes and implications for their connection to the sending country. Like many other diasporas, the Zimbabwean diaspora is fluid and diverse (Pasura, 2011). Diaspora formation and consolidation produce different levels of attachment to and detachment from the sending country in direct connection to differential degrees of attachment to and detachment from the receiving country. Bloch (2008) notes that transnational activities depend on factors such as the context in which migrants leave the sending country, the political situation in this country, and their status in the receiving country. Tsuda (2012) identifies four outcomes of migrants' settlement and integration in the receiving country in relation to transnational activities in the sending country. These outcomes can be summarized as follows:

1. A zero-sum relationship in which increased participation in one country reduces involvement in the other country.

2. Simultaneous engagement in both countries without one affecting the other.

3. Positively reinforcing simultaneous participation in which increased participation in the receiving country increases positive participation in the sending country.

4. Negative reinforcement in which decreased engagement in one country causes decreased participation in the other country. 
These outcomes are applicable to the Zimbabwean diaspora in which migrants relate with both their receiving countries and Zimbabwe to varied degrees that are influenced by factors in both Zimbabwe and the receiving countries. The zero-sum scenario is observable in three instances. In the first instance, as Tsuda (2012) notes, the initial stages of life as a migrant are characterized by detachment from the receiving country and attachment to the sending country. Prior to migrants' integration into the receiving country, they tend to direct social and economic activities predominantly to the sending country to which they orient their sense of belonging and identity. In the research in Germany, Zimbabwean migrants were in regular contact with people in Zimbabwe than those in Germany unless they were fellow Zimbabweans and their attachment to Zimbabwe was visible in their use of Zimbabwean culture to inform their behavior presented in the preceding section. The early years of migration were also characterized by regular communication with family and friends back in Zimbabwe, regular sending of remittances, and for migrants in South Africa, at least annual visits where possible especially for holidays, such as Christmas and New Year.

In the second instance, the opposite may happen in the sense that migrants may feel attached to the receiving country even in the early stages of life as migrants leading to detachment from the sending country. It is thus not always the case that migrants are attached to the sending country in the early stages of life as a migrant. Detachment from the sending country in the early years of life in the receiving country can be attributed to experiences in Zimbabwe prior to migration that can result in migrants seeking to erase memories from the country especially if these experiences directly led to migration. For example, John who fled political persecution focused more on building a future in Germany although he left his wife and children in Zimbabwe. He seemed to plan his life around new relationships in German than around his wife and children back in Zimbabwe. In such cases, the bond with Zimbabwe slackened as family and friends back in Zimbabwe were displaced by new relationships in Germany and South Africa or immediate family in Zimbabwe relocated to Germany or South Africa for family reunion. This can be attributed to asylum policies that do not allow asylum seekers who have been granted refugee status to return to their countries of origin (see Block, 2008). This policy can be combined with refugees not being allowed to work which in turn limits their transnational capabilities such as the capacity to send remittances.

The third instance of a zero-sum outcome characterized by growing attachment to one country corresponding with detachment from the other can also be observed in situations where migrants' parents had died and the migrants' siblings had left the country for the same country as the migrants or for other destinations altogether. After more than two decades of living outside Zimbabwe, both communication and visits to the country have significantly declined as migrants embrace the receiving country as their home and the country of origin 
as a background which they visit because of existing family ties (see also Pasura, 2010). As migrants form new families in the diaspora, sending of remittances may become infrequent as obligations shift to raising a young family in the receiving country. Thus, as their attachment to the receiving country increases, absence of immediate family members in Zimbabwe due to death or migration can lead to detachment from Zimbabwe as migrants stop sending remittances to the country.

There is also a temporal dimension to the zero-sum transnational outcome. During the first phase of the research in 2006-7, migrants who arrived in Germany in the early to mid-1990s before the crisis and had spent more time in the country than those who arrived at the turn of the twenty-first century sounded a bit detached from Zimbabwe and stated that they did not intend to return to live in the country although they still had family there. By the time the research was conducted, they had been in Germany long enough to have learnt German and acclimatized to the country. In this category was a man who moved to Germany as a student in the 1990s before the onset of the crisis in Zimbabwe. At the time of the research, he had married a Germany woman and started a family. Although he occasionally visited his family in Zimbabwe, he categorically stated that he did not intend to return for the long-term because Zimbabwe would be difficult for his wife and would not avail to his son the same prospects and opportunities as Germany did. This case illustrates that with passage of time and birth of a new generation that has no experience and memory of Zimbabwe by virtue of being born outside the country, Zimbabwe generally recedes to the background for migrants who have started families in Germany. These sentiments were echoed by migrants who moved to Germany and South Africa when their children were still young and were raised in the receiving country. Although migrants in South Africa still visited Zimbabwe, the intractable economic and political challenges in Zimbabwe combined with birth of children in South Africa had gradually transformed the latter into home. In general, migrant parents did not want their children to live in Zimbabwe because they believed that the country would not give them the same opportunities they saw in Germany and South Africa and had grown up with and become used to.

The second outcome where migrants participate in both countries simultaneously without engagement in one affecting the other was observable in cases where migrants had adapted to and integrated into Germany and South Africa without severing ties to Zimbabwe. Establishment of bonds with the receiving countries does not necessarily translate into breaking of ties with Zimbabwe. Rather, migrants maintain differential levels of attachment to Zimbabwe and while the receiving country becomes their legal home, Zimbabwe remains their cultural and social home (Biri, 2014; Pasura, 2010). They strike a balance in the sense of investing their social and economic resources in Germany and South Africa without this reducing the level of engagement in Zimbabwe. This is the phase when they 
start developing economic and social ties to Germany and South Africa without reducing or erasing their attachment to Zimbabwe. It is a phase characterized by development of transnational activities in which economic and social investment in the receiving country is not to the detriment of investment in Zimbabwe. Joe's case is illustrative of this transnational outcome. His high paying job in Germany enabled him to buy a house in Germany and at the same time start building another house back in Zimbabwe. In South Africa, xenophobic attacks remind the migrants that as much as they have become integrated into the country and developed a sense of attachment to it, they remain outsiders or foreigners who are criminalized, discriminated against, abused, and subjected to violence (Alfaro-Velcamp, Shaw, 2016; Mosselson, 2010; Solomon, 2019). In view of the sense of not belonging and uncertainty that xenophobic attacks engender among the migrants, those who have bought homes or acquired citizenship in South Africa did not sell the houses they left behind in Zimbabwe. Indeed, more migrants refer to xenophobia as a reminder that, in the words of Joy, one of the migrants, "South Africa is not home". This spurs migrants towards building homes in Zimbabwe and ensuring that they can live comfortable lives should they be forced to abandon their lives in South Africa and return to Zimbabwe. Agatha, stated that it was important to have a house in Zimbabwe because one could be forced by xenophobic attacks to return to the country "anytime" and one needed to "be prepared all the time".

The third outcome involving participation being simultaneously reinforcing is observable in instances where migrants have embraced the receiving country as a place they will live in for the long haul. With more years spent in Germany or South Africa, the migrants have become established enough to be able to create stronger social ties and change their legal status which signals the idea of Germany or South Africa becoming home to them. At the same time, Zimbabwe remains on their radar because of its relevance to their future plans. In view of this, the more economically integrated in Germany they become, the more money they are able to save for investment in retirement in Zimbabwe. As much as Germany and South Africa have become home, Zimbabwe remains part of their future especially after retirement so it remains home as well. Cerase (1974) presents retirement as one instance in which migrants return to the sending country to spend the remainder of their lives among family and friends and also to be buried in the country of birth. Various factors account for the desire to spend the remaining years of their lives in Zimbabwe. These include high cost of care institutions for the elderly in Germany and fear of loneliness and racism in old age when their spent bodies require them to depend on others. Increased engagement in both countries is partly influenced by the distance of the receiving country from Zimbabwe. It is cheaper and therefore easier for migrants in South Africa to travel to Zimbabwe than it is for migrants in Germany to do the same. The latter's continued attachment to Zimbabwe mostly thrives on communication technology than on actual visits to the country. 
In the fourth and last outcome characterized by negative reinforcement, Zimbabweans who have failed to achieve their migration goals tend to reduce engagement in Zimbabwe primarily due to lack of resources to invest there and also reluctance to socially engage which is intended to avoid sharing stories of shattered dreams with family and friends back in the country. Social ties become tenuous when migrants cannot send the remittances that those who remain in Zimbabwe often expect. This last outcome is salient to the Zimbabwean diaspora because the expectation in Zimbabwe for migrants to achieve the goals that made them migrate is very high. Many migrants sever ties completely because they do not want to become the object of ridicule in Zimbabwe especially in a broader context where other migrants are investing in the country. This is illustrative of how transnational capabilities impact on transnational activities (Bloch, 2008). In this sense, lack of capabilities or means reduces or negatively impacts on transnational activities. This is in contrast to Cerase's (1974) return of failure in which migrants return to the sending country when they fail to meet their migration goals. In this instance, both migrants' unfavorable economic circumstances in either Germany or South Africa intersect with equally unfavorable socio-cultural factors in Zimbabwe in the form of reactions to these economic circumstances. This negative combination produces detachment from a sending country that has high expectations that the migrants cannot fulfil and a receiving country which cannot provide ways to fulfil these expectations.

In recent times, the differential levels of attachment to and detachment from Zimbabwe have become even more stark due to the fact that the amount of time that has lapsed since migration has been long enough for migrants to make decisions based on concrete factors in Zimbabwe rather than on prognosis. Migrants' perception and interpretation of these factors are varied and depend on the transnational outcome that applies to them. Their attitudes towards Zimbabwe are "contingent, and constantly shifting" (Pasura, 2010, p. 1456). For example, when President Robert Mugabe was ousted from power in November 2017, many Zimbabwean migrants who were interviewed by the media in South Africa expressed the view that they were happy as they were now in a position to return to their country. However, a few months later when the anticipated positive political and economic change did not materialize, the hope to return to Zimbabwe was dashed and, in some instances, replaced by the opposite decision to now firmly establish themselves outside Zimbabwe. Some migrants who initially left houses in Zimbabwe with the hope that they would go back to live in them once the crisis had been resolved have returned to the country to sell them thus signaling transition from simultaneous attachment to both the sending and receiving countries to a zero-some outcome in which attachment to the receiving country has resulted in complete detachment from Zimbabwe. Pasura (2010) notes that as migrants think of long-term settlement in the receiving country, investment in Zimbabwe declines as migrants buy properties in the United Kingdom. 
Zimbabwe itself has contributed to this detachment through intractability of the economic and political reasons for migration thus dashing migrants' hope to return. In other words, the initial "waiting" mode has transformed into permanent settlement thus demonstrating the fluidity of levels attachment and detachment to Zimbabwe and the concomitant transnational outcomes. Transnational outcomes can morph into each other over time as the example of people who had initially maintained regular contact with Zimbabwe sever it in reaction to changing circumstances in both Zimbabwe and South Africa or Germany. They are also varied in the sense of some Zimbabwean migrants traveling to Zimbabwe to dispose of the assets they had left there while others return to invest in businesses and build houses. Connection to Zimbabwe can thus be described as an "evolving and uneven force" (Clayton, Manyena, 2020, p. 14). Recently, a Zimbabwean migrant who had traveled from the United Kingdom to Zimbabwe for business died there and her remains were repatriated to the United Kingdom. Comments below a YouTube video of her funeral predominantly expressed surprise and incomprehension at the idea of the body being sent to the United Kingdom for burial. ${ }^{1}$ This was in contrast to many instances in which migrants who have spent years without visiting Zimbabwe are repatriated to the country for burial when they die. Different levels of attachment to and detachment from the sending and receiving countries thus influence migrants' sense of identity and belonging; where Zimbabwe is part of the past for some migrants, it remains part of the future for others. This portrays the term diaspora as characterized, in the words of Patterson and Kelley (2000, p. 20) by "complexities and contradictions".

\section{Conclusion}

The Zimbabwean diaspora grew in the last two decades when unprecedented numbers of people left the country. Intractability of economic and political problems that led to migration out of Zimbabwe transformed what was previously envisaged as waiting for the crisis in Zimbabwe to abate to long-term settlement. This settlement has produced a spectrum of transnational outcomes in which migrants can be situated based on their level of attachment to and detachment from either Germany and South Africa or Zimbabwe. The Zimbabwean diaspora is thus characterized by heterogeneity manifest in how migrants' varied circumstances and experiences produce varied transnational outcomes. However, change in migrants' circumstances can result in corresponding change in the type of transnational

\footnotetext{
"A Case of Reverse Repatriation. UK Burial of Pamela Mushinga who Died in Zimbabwe." One comment on the video read "Why would anyone choose to be buried in a foreign land when they died in their home country? Make [sic] make sense?" While a number of the comments expressed the sentiment captured in this question, there were others that took the view that her burial wishes need to be respected. These comments show the varied understanding of migration and attachment and detachment as well as belonging especially to the sending country. Available at: $<$ https://www.youtube.com/watch?v=hRdZfdd1pQM >. Accessed on 18.04.21.
} 
outcome the migrants find themselves in. Transnational outcomes as illustrated by the Zimbabwean diaspora are fluid and fluctuating. Levels of attachment to Zimbabwe are not only shaped by migrants' current circumstances. Rather, they are also influenced by future intentions such as those relating to retirement plans and the uncertainty of long-term plans in the receiving country as can be observed in the case of migrants whose stay in South Africa has become tenuous because of concern generated by intermittent xenophobic attacks mostly on African migrants. Conversely, Zimbabweans who envision the receiving country not only as their present but also as their future make corresponding adjustments that can result in a zero-sum outcome in which their attachment to the receiving country results in detachment from the sending country. This can be noted among Zimbabweans who sought asylum in Germany and those who have economically established themselves in Germany, started families with German spouses, and do not intend to return to Zimbabwe.

\section{References}

AL-ALI, Nadje; BLACK, Richard; KOSER, Khalid. The Limits to 'Transnationalism': Bosnian and Eritrean Refugees in Europe as Emerging Transnational Communities. Ethnic and Racial Studies, v. 24, n. 4, p. 578-600, 2001.

ALEXANDER, Jocelyn; McGREGOR, JoAnn. 2013. Introduction: Politics, Patronage and Violence in Zimbabwe. Journal of Southern African Studies, v. 39, n. 4, p. 749763, 2013.

ALFARO-VELCAMP, Theresa; SHAW, Mark. 'Please GO HOME and BUILD Africa': Criminalising Immigrants in South Africa. Journal of Southern African Studies, v. 42, n. 5, p. 983-998, 2016.

BIRI, Kudzai. Migration, Transnationalism and the Shaping of Zimbabwean Pentecostal Spirituality. African Diaspora, v. 7, n. 1, p. 139-164, 2014.

BLOCH, Alice. Zimbabweans in Britain: Transnational Activities and Capabilities. Journal of Ethnic and Migration Studies, v. 34, n. 2, p. 287-305, 2008.

CASTLES, Stephen. Social Transformation and Human Mobility: Reflections on the Past, Present and Future of Migration. Journal of Intercultural Studies, v. 39, n. 2, p. 238-251, 2018.

CERASE, Francesco. Expectations and Reality: A Case Study of Return Migration from the United States to Southern Italy. International Migration Review, v. 8, n. 2, p. 245-262, 1974.

CLAYTON, John; MANYENA, Bernard. Diasporic Reorientations: Emotional Geographies of the Zimbabwean Diaspora in a Post Mugabe Era. Journal of Ethnic and Migration Studies, p. 1-18, 2020.

CRUSH, Jonathan; CHIKANDA, Abel; TAWODZERA, Godfrey. The Third Wave: Mixed Migration from Zimbabwe to South Africa. Canadian Journal of African Studies/ Revue canadienne des études africaines, v. 49, n. 2, p. 363-382, 2015. 
CRUSH, Jonathan; TEVERA, Daniel. Exiting Zimbabwe. In: CRUSH, Jonathan; TEVERA, Daniel (eds.). Zimbabwe's Exodus: Crisis, Migration, Survival. Cape Town: SAMP, 2010, p. 1-49.

de JAGER, Nicola; MUSUVA, Catherine. The Influx of Zimbabweans into South Africa: A Crisis of Governance that Spills Over. Africa Review, v. 8, n. 1, p. 15-30, 2016.

HANKE, Steve H.; KWOK, Alex K. F. On the Measurement of Zimbabwe's Hyperinflation. Cato Journal, v. 29, n. 2, p. 353-364, 2009.

JAJI, Rose. Deviant Destinations: Zimbabwe and North to South Migration. Lanham, MD: Lexington Books, 2020.

JEFFERIS, Keith. Zimbabwe's Currency 'Curse' and the Economic Malaise. Institute for Security Studies. Policy Brief 140, 2020. Available at: < https://media.africaportal. org/documents/Zimbabwes_currency_curse.pdf>. Accessed on: 17.04.21.

KAWEWE, Saliwe M.; DIBIE, Robert. The Impact of Economic Structural Adjustment Programs [ESAPs] on Women and Children: Implications for Social Welfare in Zimbabwe. The Journal of Sociology \& Social Welfare, v. 27, n. 4, p. 79-107, 2000.

MAIYAKI, Ahmed A. Zimbabwe's Agricultural Industry. African Journal of Business Management, v. 4, n. 19, p. 4159-4166, 2010.

MLAMBO, Alois. A History of Zimbabwean Migration to 1990. In: CRUSH, Jonathan; TEVERA, Daniel (eds.). Zimbabwe's Exodus: Crisis, Migration, Survival. Cape Town: SAMPA, 2010, p. 52-76.

MOSSELSON, Aidan. 'There is no Difference between Citizens and Non-citizens Anymore': Violent Xenophobia, Citizenship and the Politics of Belonging in Post-Apartheid South Africa. Journal of Southern African Studies, v. 36, n. 3, p. 641-655, 2010.

PASURA, Dominic. Competing Meanings of the Diaspora: The Case of Zimbabweans in Britain. Journal of Ethnic and Migration Studies, v. 36, n. 9, p. 1445-1461, 2010.

PASURA, Dominic. Toward a Multisited Ethnography of the Zimbabwean Diaspora in Britain. Identities, v. 18, n. 3, p. 250-272, 2011.

PATTERSON, Tiffany R.; KELLEY, Robin D. G. Unfinished Migrations: Reflections on the African Diaspora and the Making of the Modern World. African Studies Review, v. 43, n. 1, p. 11-45, 2000.

RAFTOPOULOS, Brian; SACHIKONYE, Lloyd. Striking Back: The Labour Movement and the Post colonial State in Zimbabwe 1980-2000. Harare: Weaver Press, 2001.

SACHIKONYE, Lloyd. Industrial Restructuring and Labour Relations Under ESAP in Zimbabwe. In: GIBBON, Peter (ed.). Structural Adjustment and the Working Poor in Zimbabwe. Uppsala: Nordiska Afrikainstitutet, 1995, p. 38-131.

SOLOMON, Ryan. Xenophobic Violence and the Ambivalence of Citizenship in Postapartheid South Africa. Citizenship Studies, v. 23, n. 2, p. 156-171, 2019.

TSUDA, Takeyuki. Whatever Happened to Simultaneity? Transnational Migration Theory and Dual Engagement in Sending and Receiving Countries. Journal of Ethnic and Migration Studies, v. 38, n. 4, p. 631-649, 2012. 